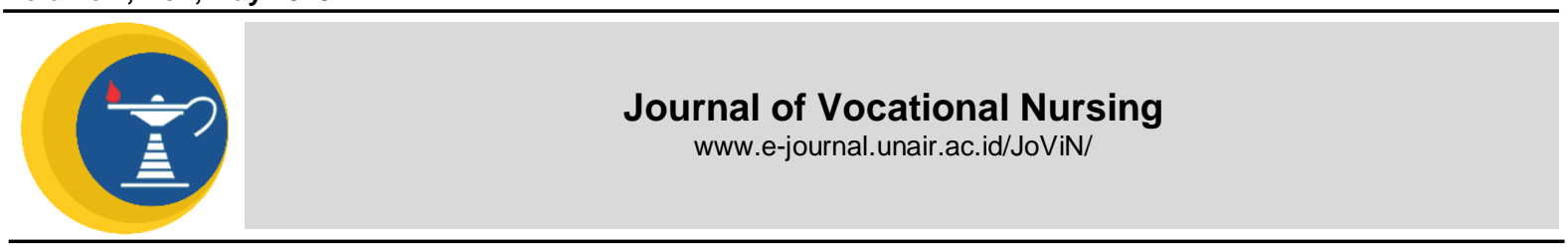

\title{
RELATIONSHIP BETWEEN COPING STRESS STRATEGIES AND STRESS LEVELS IN POST DIVORCE WOMEN IN TUBAN RELIGIOUS COURTS
}

Research Report

Nurus Safaah ${ }^{1}$, Faridatus Saidah ${ }^{2}$

1,2 School of Nursing Nahdlatul Ulama Intitute of Health Science Tuban

\section{ABSTRACT}

Introduction: Divorce is a complex problem for woman because it is an event that can cause psychological problems that have an impact on daily life causing stress. One way to deal with stress is to use the right coping stress strategy. The purpose of this study was to determine the relationship of coping stress strategies with stress levels in post-divorce women in the Tuban religious court.

Methods : The study design uses correlation analytic with cross sectional time approach. The study population numbered 50 post-divorce women in the Tuban religious according to inclusion and exclusion criteria, the research sample used simple random sampling totaling 42 respondents. The independent variable is the stress coping strategy, while the dependent variable is the stress level. The instruments used ware the revised Way of Coping Questionnaire (WOCQ) and (Depression Anxiety Stress Scales) DASS 42 questionnaire.

Results : The results of study were almost 14 (33.3\%) post-divorce women using problem focused coping (PFC) coping strategies experienced mild levels of stress and a small percentage of 1 (2.4\%) respondents used emotion focused coping (EFC) coping strategies severe stress level. Contingency coefficient test results obtained $p=0.004$ if the value of $\alpha=0.05$, then $p<\alpha$ with moderate accuracy $(c=0.494)$.

Conclusion : Based on the description, it can be concluded that there is a relationship between coping stress strategies and the level of stress in women after divorce in the Tuban religious court. Choosing the right coping stress strategy is very important to deal with stress levels in post-divorce women.
ARTICLE INFO

Recived 17 December 2019

Accepted 6 May 2020

Online 29 May 2020

*Correspondence:

Nurus Safaah

*Email:

nurus.shona@gmail.com

Keywords:

Divorce, Emotion Focused

Coping,Problem Focused

Coping,Stress

\section{INTRODUCTION}

Marriage explains that marriage is an inner and spiritual bond between a man and a woman as husband and wife with the aim of forming a happy and eternal family (household) based on the Godhead of the Almighty (Law No. 1 of 1974 article 1). In fact, it is rare for a husband and wife who live together to live life without disputes, in the household, disputes and quarrels between husband and wife are common, but this is the beginning of divorce (Sumarni \& Kasmawati, 2016). Divorce occurs due to the existence of one of the parties who committed the affair, the husband does not provide good care physically and mentally to his wife, there is persecution that endangers the health of one party (Kusuma, 2012).

In Indonesia the number of divorces continues to increase every year, it can be seen from the exposure of the religious life research center (Puslitbang) of the Ministry of Religion (Ministry of Religion) which states that in 2010 the number of divorced individuals amounted to 251,208 cases, while in 2014 it reached 382,231 cases and in badilag reporting MA (2014) there are regions that have the highest divorce rates in divorce cases, namely: East Java (63,406 cases) (Jazuli, 2018). Based on a source from the Tuban Religious Court Tracing Information System, from 2015 to 2018 there 
were approximately 10,900 cases of lawsuits, namely 10,909 cases entered and 10,967 cases dropped out, it can be said that the divorce rate in Tuban district is still high, with an average annual rate of 2,727 cases entered and 2,742 cases broke up.

Ria (2000) states that women will be stressed and asked themselves. The changing status of women from marital status to widowed status is an adaptive change that is not easily done by individuals so that the change will bring pressure that is either physiologically or psychologically (Aisha, 2012). Divorce will lead to several conflicts that must be resolved by informants, conflicts experienced by informants received from the psychological, economic and social aspects. On the psychological side, informants will change their traumatic attitudes and experiences.

Then for the economic side, the informants will be completed in meeting the needs of life. Informants must support all needs with their own work.
Then on the social side, informants will get cynical conversations obtained from neighbors and the community (Soniawati, 2018) so that women after divorce will experience a lot of pressure and convincing that will make someone stressed.

Stress situation experienced by a person will cause adverse effects both physiological and psychological, the individual will not ask for negative effects to continue to occur, he will take action to overcome them, the actions taken by individuals are called coping strategies (Lazarus and Folkman, 1984 in Maryam, 2017).

\section{MATERIALS AND METHODS}

This research is a quantitative study using a correlation analytic research design. In this study the researchers took the subjects based on criteria, where the respondents of the researchers did were women after divorce in Tuban religious court as many as 42 women with random sampling techniques, namely random sampling without regard to specific strata. Data collection methods used are the revised WOCQ questionnaire and DASS 42 (Deppretion, Anxiety, stress) from Lovbidond \& Lovbidond (1995).

\section{RESULTS}

Characteristics of Respondents

Table 1 Frequency Distribution of Post-Divorce Women by Age in the Tuban Religious Courts in 2019

\begin{tabular}{cccc}
\hline No & Age & Frequency & Percentage \\
\hline 1. & $17-25$ Years & 4 & $9 ., 5$ \\
2. & $26-35$ Years & 23 & 54,8 \\
3. & $36-45$ Years & 11 & 26,2 \\
4. & $46-55$ Years & 2 & 4,8 \\
5. & $56-65$ Years & 2 & 4,8 \\
\hline
\end{tabular}

Shows that the majority of respondents aged 26-35 years were $23(54.8 \%)$ and a small proportion aged $46-55$ years and 56-65 years were $2(4.8 \%)$.

Table 2 Frequency Distribution of Post-Divorce Women Based on Education in the Tuban Religious Court in 2019

\begin{tabular}{cccc}
\hline No & Education & Frequency & Percentage \\
\hline 1. & No school & 0 & 0 \\
2. & Primary school & 0 & 0 \\
3. & Junior high school & 21 & 50,0 \\
4. & Senior high school & 14 & 33,3 \\
5. & Scholar & 7 & 16,7 \\
\hline & Total & 42 & 100
\end{tabular}

Shows the education level of the respondents half of the respondents having a junior high school education were $21(50,0 \%)$ and a small portion had a university education level of $7(16,7 \%)$. 
Table 3 Frequency Distribution of Post-Divorce Women by Occupation in the Tuban Religious Court in 2019

\begin{tabular}{cccc}
\hline No & Job & Frequency & Percentage \\
\hline 1 & Housewife & 13 & 31,0 \\
2 & Private worker & 23 & 54,8 \\
3 & Civil servant worker & 6 & 14,3 \\
\hline \multicolumn{6}{c}{ Total } & 42 & 100 \\
\hline
\end{tabular}

Shows the work of the majority of respondents private workers by $23(54,8 \%)$ and a small proportion of civil servant workers by $6(14,3 \%)$.

Table 4 Frequency Distribution of Post-Divorce Women by Type of Divorce in the Tuban Religious Court

\begin{tabular}{|c|c|c|c|}
\hline No & Divorce & Frequency & Percentage \\
\hline 1 & Divorced claims & 29 & 69,0 \\
\hline 2 & Divorce divorces & 13 & 31,0 \\
\hline
\end{tabular}

Shows the types of divorce respondents mostly are divorce claims by $29(69.0 \%)$ and a small portion of respondents for divorce types are divorce divorces by $13(31.0 \%)$.

Table 5 Frequency Distribution of Coping Stress Strategies in Post-Divorce Women in the Religious Court of Tuban in 2019.

\begin{tabular}{cccc}
\hline No & $\begin{array}{c}\text { Coping Stress } \\
\text { Strategies in Post- } \\
\text { Divorce }\end{array}$ & Frequency & Percentage \\
\hline 1 & $\begin{array}{c}\text { PFC } \\
\text { (problem focused coping) } \\
\text { EFC }\end{array}$ & 24 & 57,14 \\
2 & (emotion focused coping) & 18 & 42,86 \\
\hline & Total & 42 & 100 \\
\hline
\end{tabular}

Found that most respondents had a PFC stress coping strategy of $24(57.14 \%)$ and almost half of the respondents had an EFC stress coping strategy of 18 (42.86\%).

Table 6 Frequency Distribution Stress in Post-Divorce Women in the Religious Court of Tuban in 2019

\begin{tabular}{cccc}
\hline No & Stress in Post-Divorce Women & Frequency & Percentage \\
\hline 1 & Normal & 8 & 19,0 \\
2 & Mild & 18 & 42,9 \\
3 & Moderate & 15 & 34,7 \\
4 & Severe & 1 & 2,4 \\
5 & Very severe & 0 & 0 \\
\hline & & 42 & 100
\end{tabular}

Shows that almost half of respondents experienced mild stress by $18(42,9 \%)$ and a small proportion of respondents experienced severe stress by $1(2,4 \%)$.

Table 7 Cross Table of Relationship of Coping Stress Stress Level in Post-Divorce Women in the Religious Court of Tuban in 2019.

\begin{tabular}{ccccccc}
\hline \multirow{2}{*}{$\begin{array}{c}\text { Strategi } \\
\text { Coping }\end{array}$} & Normal & Mild & Moderate & Severe & Very Severe & \multirow{2}{*}{ Total } \\
\hline PFC & $6(25 \%)$ & $14(58,3 \%)$ & $4(16,7 \%)$ & $0(0 \%)$ & $0(0 \%)$ & $24(100 \%)$ \\
EFC & $2(11,1 \%)$ & $3(16,7 \%)$ & $12(66,7 \%)$ & $1(5,6 \%)$ & $0(0 \%)$ & $18(100 \%)$ \\
\hline Total & $8(19 \%)$ & $17(40,5 \%)$ & $16(38,1 \%)$ & $1(2.24 \%)$ & $0(0 \%)$ & $42(100 \%)$ \\
\hline
\end{tabular}


The results of the study show that almost some of the respondents using the coping stress strategy PFC experienced mild stress by $14(33,3 \%)$ and a small portion of respondents using the coping stress strategy EFC experienced severe stress by $1(2,4 \%)$. there is a relationship between coping stress strategies with women's stress levels after divorce using the contingency coefficient test with the results of the analysis obtained significance $p=0,004 c=0,495(0,5)$ and significant value $=0,05$. This shows that the value of $p<\alpha(0.004<0.05)$ with moderate strength or accuracy $(c=0,5)$.

\section{DISCUSSION}

The results of interpretation of the data obtained by researchers explain that of the 42 most respondents, 24 (57.14\%) respondents used the PFC coping strategy.

The results of the analysis state that the coping stress strategy used by post-divorce women is PFC, which is one of the ways used by post-divorce women in overcoming or minimizing their experiences, coping strategies chosen by PFC because post-divorce women tend to seek moral and social sympathy and support from people surrounding.

Likewise, according to Lazarus and Folkman (in Mariam 2017) coping strategies stress problem focused coping (PFC), including good strategies used to change the situation, atmosphere or goals by changing according to the environment or by seeking social support in the family or the sorruonding environment.

The analysis shows that one of the factors that influence the selection of coping stress strategies is work, where women workers either private or civil servants will tend to choose the PFC coping strategy because it can divert the problem by doing work,more often discussed with other people or coworkers to get sympathy and also improve on the economic side of the family after divorce occurs. meanwhile women who are not working or just as housewives (IRT) will prefer the EFC coping strategy because an IRT will be more often in the house so that they are more often alone and only exercise emotional control such as worship and self-reflection.

According to Lazarus and Folkman in Maryam (2017) that the strategy of coping stress PFC (problem focused coping) is a strategy carried out by someone with a focus on problem solving namely people who have activities outside the home or spend a lot of time outside the home such as working and organizing. PFC itself consists of 3 aspects, namely planfull problem solving (the focus of solving problems for the next life), seeking social support (seeking sympathy or attention from others), confrontative coping (efforts to get out of a tense situation). EFC (emotioan focused coping) stress coping strategy is a strategy carried out by someone by controlling emotions or self-introspection that is done by people who do not spend much time outside the home or more often alone so more often communicate to himself. EFC itself consists of 5 aspects of positive reappraisal (positive thinking) such as multiplying worship, Accepting responsibility (emphasis on responsibility), Self controlling (self control), Distancing (keeping distance), Escape avoidance (avoiding oneself).

The results of the analysis state that the influencing factors are education which is a human level in the process, many lessons and experiences gained from the education level thus making someone with different thoughts and ideas and changing patterns of thought at every level or level. The higher the level of education the better the coping strategy used is to tend to use the PFC strategy, in this study the minimum level of high school education shows the use of the PFC stress coping strategy because someone who is more educated the way to solve the problem is better, namely by solving or dealing with existing problems with various plans and the methods they have based on experience and knowledge. Whereas in the research of women with junior high school education level they tend to use the EFC stress coping strategy because someone's education level affects the mindset and the way the problem is solved that is based on experience and knowledge so that because the level of education is lower then the experience and knowledge in problem solving will be lower by not directly solving the problem but rather to control emotions that capture that everything that happens as a good destiny is bad destiny or good destiny so that it will take longer to adapt to the problem.

According to Pramadi and Lasmono (2003) someone who has a high level of education has a bold mindset in taking a stand to overcome the problem and not procrastinating, because it will further increase the burden of thought, it can also be interpreted that someone with a high level of education will tend to use problem focused coping in solving problems.

the results of the analysis show the type of divorce is a factor that influences a person's coping stress strategy, it happens because post-divorce women with divorce divorce types use the PFC coping stress strategy, because divorce is a divorce where the request for 
divorce or claimant comes from the woman or wife, it is considered to be one of the ways or solutions used by women (wife) to resolve stressful situations or situations experienced in the household, with a post-divorce (widowed) women's PFC strategy with a divorce more plans for the future and look for sympathy or attention to the surrounding environment to get support.

According to Lazarus and Folman (in Mary 2015) that coping strategies focusing on problems (PFC) are actions directed at solving problems, preparing plans, changing situations and seeking social support. Individuals will tend to use this behavior if he assesses the problems he faces can still be controlled and can be solved.

The results of interpretation of the data obtained by researchers explain that from 42 research respondents nearly half of respondents experienced mild stress by 17 $(40.5 \%)$ experiencing mild stress levels.

The results of the analysis state that post-divorce women experience mild stress because most divorce cases are divorce, where divorce occurs because of a woman's will, it still disturbs or makes a stressor for a woman because of changing circumstances and the many demands, but it is also one solution to the problem from the household conflict he experienced, so that divorce is considered as a risky solution that must be borne after the divorce occurs.

According to Hawari (2013) said that stress according to Hans Selye is a non-specific body response to each load load. Psychosocial stressors are any events or circumstances that cause changes in someone's life, so that a person must adapt or adjust to deal with them.

The results of the analysis state that one of the factors that influence stress levels is age, age 25-35 years is a mature age that is associated with the level of maturity in question is the way or attitude in overcoming the problems they are experiencing and at this age physical and psychological conditions in the best conditions, so as to control the stress level. $t$ the age of 36-45 years, they tend to experience normal stress because at that age the level of perfection maturity is higher the pattern of emotional control is better and someone is in a stable period. whereas at the age of 17-25 years tend to experience moderate levels of stress because at this age is the age at the stage of searching for identity vs. confusion vs intimacy and participation so that when a relationship is formed unsuccessfully it will cause confusion even the role of isolation, at age $45-55$ years and $55-65$ someone is at the stage of ego vs. integrity where a person's attitude will begin to return like a teenager whose thinking patterns and emotions are still unstable so that when he is in a problem or stressor that is unable to deal with it will cause moderate stress even weight. As stated by Mapiarre in Sijangga (2010) that age has a close bond with life, the more age has a close bond with life, the more age the more capable a person is in making wise decisions, showing emotional maturity and controlling emotions and being more skilled at running the task so that the problem can be solved properly.

According to Ericson the psychosocial stage of the age of 12-20 years is identity and confusion of roles, age 20-24 years of intimacy and isolation, age $25-65$ years of generativity and stagnation, the age of 65-end is the integrity of the ego and decisions.

The results of the analysis state that someone who is highly educated will gain a lot of experience and have many ways or ideas to solve the problem and have a different perspective on a problem, so the higher the level of education a person will be better at dealing with tense conditions or problems that occur in him In this study, women with a bachelor's level of stress tend to be normal because of their higher level of experience and knowledge so they are able to control their stress levels or are able to deal with stressors well. Women with high school education tend to experience mild stress levels because their experience and knowledge are quite good, while women with junior high school education levels tend to experience moderate stress levels and some are even heavy because of their experience and knowledge in dealing with stressors less so it is difficult to minimize the level of stress they experience.

This is in line with what was conveyed by Mubarok (2012) that education is guidance given to someone to others in order to understand a matter. The lower the education level of a person, the development of someone's attitude towards receiving information and new values introduced will also be hampered. Conversely, the higher a person's level of education, the easier they will obtain information and receive well so that the more knowledge and experience they have.

According to researchers work is one of the factors that influence a person's stress level where when a woman is divorced working at home or as a housewife will be more saturated and focused on the problems experienced such as easier to remember memories, not much interacting with others and routine activities that are repeated every day

This triggers a person's stress level higher than women who work outside who are 
able to interact with people around so they are not easily remembered by memories. In this study women working as civil servants tended to experience normal stress levels because the level of anxiety in dealing with family finances after divorce was lighter because they felt that their income was sufficient and there were retirement benefits. For women with private work tend to experience mild stress levels because women with private workers fear or anxiety levels in dealing with family finances after divorce are lighter so they feel able to finance their own life and family without a husband despite the absence of retirement benefits While women with IRT workers tend to experience moderate stress levels even severe because there is anxiety the inability to meet family finances after divorce because of the absence of a husband.

According to Saras Damaske, a professor of labor and employment at Pennsylvania State University in the United States in her study that women feel most comfortable in the office and men feel happier when at home, this is because women do most of the housework than man, because stress can come from a tiring and boring daily routine. Even from the results of his research showed test results of higher levels of cartisol in IRT (housewives) than in women workers (Febrida, 2014).

The results of the analysis state that the type of divorce is a factor that influences a person's stress level. from the woman or wife, This is considered to be one of the ways or solutions that women (wives) use to solve stressful situations or situations experienced in the household even though divorce is considered as the last solution which basically every woman never wants it to happen, so the level of stress she experiences lower.

According to Yulia, an alumnus of S1 Psychology at the Islamic University of Indonesia (in Suryowati 2019) in her research that divorce triggers stress because it causes financial problems, accounts receivable, and assets of gono-gini. so you have to prepare yourself mentally about the new status as a widow and economic problems and jobs that must be taken. A woman with a divorce will prepare for it earlier than a woman with divorce divorce, because divorced women claim for divorce or the plaintiff comes from the woman (wife) while divorce divorce request for divorce or the applicant comes from the man (husband) then ready not ready a wife must accept the divorce.

The results of the analysis showed a relationship between coping stress strategies with stress levels in post-divorce women in
Tuban religious court based on the contingency coefficient test obtained significance results $p=$ $0.004 \mathrm{c}=0.495(0.5)$ and significant value $=$ 0.05 . This shows that the value of $p<\alpha(0.004$ $<0.05)$ with moderate strength or accuracy $(\mathrm{c}=$ $0.5)$.

According to Lazarus and Folkman (in Nursalam 2016) that problem focused coping (PFC) includes a good strategy used to change the situation, atmosphere or goals by changing according to the environment or by seeking social support to the family or the surrounding environment.

The analysis shows that respondents who use PFC stress coping strategies experience lighter stress levels, and respondents using EFC coping stress strategies experience heavier stress levels, because post-divorce women who make an effort to get emotional comfort such as sympathy and attention of others and focus on the future or the next life can reduce or minimize the level of stress, whereas post-divorce womenthose who make efforts to control their emotions have not been able to completely reduce their stress levels because they only consolidate on their own so that it takes more time to adapt.

\section{CONCLUSION}

The coping strategies of post-divorce stress women in the Tuban religious court mostly use the PFC coping strategy because they are influenced by several things among them, the level of education, employment and type of divorce. And almost some experience mild stress because it is influenced by several things among them, age, level of education, employment and type of divorce. So there is a relationship between coping stress strategies with stress levels in post-divorce women in the Tuban religious court that respondents who use the PFC stress coping strategy experience lighter stress levels, and respondents using the EFC coping stress strategy experience more severe stress levels.

\section{REFERENCES}

Ayesha. (2012). Psychological Impacts and Post-Divorce Women's Coping Mechanisms. Junal Piscosciences Vol. 4 No. 2, (accessed 15 December 2018).

Atmawijaya, I. A. (2018). The Effect of Coping Strategies on Stress in Balinese Women Undergoing Triple Roles. Journal of Psychology at Sanata Darma University, (accessed 20 December 2018).

The Indonesian Department of Religion (2000). Islamic Institutional Development Ministry of 
Religion of the Republic of Indonesia. Jakarta: Directorate General.

Kusuma. (2012). Causes of Divorce. Http://digilib.umg.ac.id/download, (accessed 13 December 2018).

Lazarus and Folkam (1984) stress, appraial, coping. New York: Spinger

Lukaningsih, Z. L., \& Bandiyah, S. (2011). Health Psychology. Yogyakarta: Nuha Medika.

Maryam, S. (2018). Theory and Resources. Journal of Counseling P-ISSN $25491857 \mathrm{E}$ ISSN 2549-4279, 101-107.
Nursalam. (2016). Research Methodology. Jakarta: Medika Salemba.

Republic of Indonesia Government Regulation Number 9 of 1975 Concerning

Implementation of Law No.! 1974 About Marriage. (Http://luk.staff.ugm.ac.id/atur) accessed February 5, 2019.

Sijingga W.N (2010). Relationship Between Coping Strategies with Hypertension Pregnant Mothers. Revised from http://eprints.uns.ac.id//9289//

Smet B (1994) Health Psychology. Jakarta: Grasindo.h.14 